\title{
Sun-Drying in Traditional Brickmaking: Strategies for Achieving Efficiency
}

\author{
Mochammad Mirza Yusuf Harahap ${ }^{1}$, Rini Suryantini ${ }^{1}$, Kristanti Dewi Paramita ${ }^{1}$, Yandi \\ Andri Yatmo ${ }^{1^{*}}$ \\ ${ }^{1}$ Department of Architecture, Faculty of Engineering, Universitas Indonesia, Kampus UI Depok, Depok \\ 16424, Indonesia
}

\begin{abstract}
This study investigated the utilization of currently available energy and its implication on the ecological production of architecture materials. The study focused on the sun-drying process used by craftsmen in the traditional brickmaking process, arguing that such a practice demonstrates ways of utilizing current energy that are informed by local knowledge and are ecological. Such a brick drying process was observed at two sites of traditional brickmaking in Central Java, Indonesia. The result of the study indicated that the drying process in brickmaking utilized various exposure strategies to maximize the potential amount of heat from the sun that can be transferred to the bricks, which in turn influenced the flow of the production process. The study then discussed the potential applications of such knowledge in the modern brick manufacturing process to create a more ecological production of architecture materials.
\end{abstract}

Keywords: Architecture material; Ecology; Local knowledge; Sun-drying; Traditional brickmaking

\section{Introduction}

The population increase has contributed to a high demand for bricks in our society (Holley, 2009), triggering the industrialization of brickmaking. The production of bricks on a large scale, however, is notorious for its environmental impact (Darain et al., 2015) as it contributes to air pollution (Tahir and Rafique, 2009; Darain et al., 2015) and excessive land cultivation, resulting in a threat to the ecosystem (Singh and Asgher, 2005). The forces behind the industrialization of brickmaking have mostly ignored the threat and tend to solely emphasize the efficiency of brickmaking to meet the demand without fully considering its environmental impacts (Holley, 2009). The practice is in contrast with the spirit of positive development that not only facilitates economic activity, but also the idea of sustainability, which considers environmental impacts (Berawi, 2016; Baper et al., 2020). This is unfortunate especially considering that industrialization that utilizes recent technology could be a means of mitigating unwanted environmental impacts through its expected capability for sustainability (Yusuf et al., 2018).

Notably, the traditional brickmaking practice performed by local craftsmen on a relatively small scale is a process that is connected to the wider ecology (Atmodiwirjo et al., 2018). Traditional brickmaking is a process based on local knowledge that is focused on the environmental cycle of natural resources and using the renewable energy available in 
nature (McDonough, 1996). However, such a use of natural resources is not necessarily straightforward. Various strategies are required to attain the maximum usage of the energy that is currently available. This, in turn, influences the overall flow of production. Therefore, understanding such strategies is key to promoting energy usage that is more ecologically friendly. With this in mind, this paper attempts to explore the utilization of current energy in traditional brick production, particularly sun exposure and wind currents. This paper will begin by outlining the significance of the current energy discussion in architecture material production, focusing on the drying phase of traditional brickmaking as a model of current energy use. Then, the traditional brickmaking process that were observed will be examined, and connections will be drawn between the energy uses in brickmaking and their relation to other elements and stages in the overall production process. This exploration will be followed by the discussion of the findings of the study and the potential implication of the results on the production of architecture materials.

\section{Sun-Drying Strategies as Part of the Ecological Production of Architecture Materials}

According to various studies, traditional brickmaking production is a complex process that processes and uses natural raw materials (Kadir and Sarani, 2012; Dalkılıç and Nabikoğlu, 2017) and waste (Handayani, 2010). Traditional brickmaking is a practice that reflects local wisdom (Nuroso et al., 2018; Wahid et al., 2020), suggesting that it is an ecologically friendly system (Atmodiwirjo et al., 2018). It is a practice that applies the knowledge of the production of architecture materials in its spatial context (Atmodiwirjo and Yatmo, 2020). Traditional brickmaking utilizes natural resources and has an ecological characteristic reflected in the use of an energy form that is current: it is neither a source from the past nor is it borrowed from what the future offers (McDonough, 1996). Many research studies done on traditional brickmaking have discussed the ecological aspects of brickmaking as the utilization of various additional raw materials for creating a particular intrinsic quality of the brick (Demir, 2008), including kraft pulp (Demir, 2008), organic waste from agricultural products such as rice husk ash (Sudarsana et al., 2011), sawdust (Handayani, 2010), paper mill waste (Sarkar et al., 2017), and inorganic minerals (i.e., perlite and calcite) (Demir, 2008). Nevertheless, the utilization of current energy and its applications during the production of traditional bricks is rarely discussed.

Interest in the current form of energy was part of McDonough's proposition on the ecological process of the making of things, which consists of: using resources readily available in the environment, enabling production to cycle back to nature, and an emphasis on biodiversity (McDonough, 1996). As technology advances, the process of making things tends to involve energy sources that are not "current" but borrowed from either the past or the future (McDonough, 1996). In response to this tendency, several studies discussed the use and development of alternative fuels for firing the bricks (Lakho and Zardari, 2016). Such a search is necessary due to the increase in demand of bricks over time (Holley, 2009; Kadir and Sarani, 2012). The issues surrounding the sustainability of brickmaking hence become more and more apparent (Gomes and Hossain, 2003; Darain et al., 2015). Even the use of firewood, which is considered renewable, as a resource, is still seen as arduous due to the high demand for bricks (Tahir and Rafique, 2009; Darain et al., 2015). In addition, as there are four phases in a brickmaking process - mixing raw materials, molding the mixture into raw bricks, drying the raw bricks, and firing the dried, raw bricks (Dalkılıç and Nabikoğlu, 2017; Atmodiwirjo et al., 2018)—the need for energy during other stages of the process other than the firing process is also expected. Nonetheless, study that examines the 
use of the sun as a form of current energy, particularly within the sun-drying process of bricks, is still rarely discussed in the brickmaking literature.

The sun-drying process is also relevant to further explore the connection between humans, material, and the environment as part of the ecological system. The methods used by the craftsmen in exposing the raw bricks to the sun reflect the response toward external forces in the environment (Atmodiwirjo et al., 2018) that drives these strategies. The heat of the sun is considered a form of energy that provides not only a technical solution but also a spatial design because it is projected in a fluid and gradual manner (Sadar, 2018). These strategies also influence the flow of production as they ensure that a phase within the process could be started or continued from another phase. In this sense, such strategies are particularly vital in understanding the utilization of current energy in brickmaking and the ecological nature of such processes.

Brick-drying is a complex process as it depends on the physical mechanisms of heat distribution (Gualtieri et al., 2016): "The most important mechanism is certainly . . . the transport of mass given by the random motion of molecules. This mechanism is triggered off by the humidity gradient established between the surface and the core of the wet body" (Gualtieri et al., 2016). The drying process is also greatly influenced by the pore microstructure of the raw brick, which could affect the physical condition of the dried brick (the presence of cracks) (Gualtieri et al., 2016). From the perspective of the craftsmen, however, drying raw, molded brick consists of applying strategies to achieve adequate sun exposure and wind current. Through such strategies, the craftsmen aim to control the spaces between the raw, molded bricks when they are aligned with or stacked on one another (Dalkılıç and Nabikoğlu, 2017). The optimum spacing ensures that all the brick's surfaces are dried, and a low humidity gradient between the brick's surface and the core of the brick is established. Such strategies, though laborious (Dalkılıç and Nabikoğlu, 2017), particularly reflect the local nature of the traditional brickmaking process. The strategies also emphasize the indigenous characteristics of the traditional brick (Johanes and Wahid, 2018). The strategies consist of continuous actions of moving and arranging the brick in a particular manner that maximizes heat exposure to the brick (Dalkılıç and Nabikoğlu, 2017). This paper explores such strategies and how they influence various aspects within the traditional brickmaking process, such as the process of managing the availability and configuration of space. In doing so, it can be argued that such a process demonstrates a distinct connection between humans, materials, and the environment.

\section{Methods}

The study investigated the drying strategies and techniques performed by the traditional brick craftsmen in two sites of traditional brickmaking (Ambarawa and Welahan) in Central Java, Indonesia. The study was conducted qualitatively through field observation and interviews with the craftsmen to closely examine the practice of drying in order to investigate the interrelationship between humans, materials and the surrounding environment, each of which is part of the process (Atmodiwirjo and Yatmo, 2019). In particular, visual documentation and mapping were also conducted for the analysis as an attempt to investigate the interconnection between the methods used by the craftsmen, the need for achieving a certain level of dryness, and environmental constraints (i.e., land availability and weather conditions). The interconnections reflect the vast ranges of the craftsmen's responses to constraints. They indicate the lively and confluence performances that need to be investigated through the perspective of time (Carey, 2018). Hence, the interrelation between the craftsmen, the materials, and the site could be investigated. This study aimed to thoroughly investigate stages of the drying phase. Each of the stages were 
examined to get an overall understanding of strategies for achieving efficiency when utilizing current energy from the sun. This method was conducted in both locations and the results were integrated in the discussion to note the shared values of sun-drying strategies in the traditional brick production process.

\section{Drying Bricks: Passing and Blocking Strategies}

Ambarawa and Welahan are two of many places in Central Java where traditional brickmaking sites can be found. Both locations have high amounts of sunshine throughout the year. However, the brick production process occurs mostly during the monsoon season, which lasts from April to September. In general, a cycle of brick production could last for weeks as the firing phase requires a huge amount of raw, dried bricks to be made into a kiln. Meanwhile, producing raw, dried bricks themselves requires repeated phases of mixing, molding, and drying. Out of these three phases, drying is the one which is the most time consuming as the molded raw bricks have to go through stages of drying that each require different amounts of heat from the sun. Direct observations were performed to understand the stages of the drying phase, and interview sessions were conducted with the craftsmen to understand the process better. The interviews confirmed the data collected from direct observations.

During the drying phase of traditional brickmaking, it was found that the craftsmen's methods consisted of: (1) exposing the surfaces of the raw bricks directly to the sun, hence ensuring a maximum heat transfer to the wet, raw bricks; and (2) exposing the surfaces of the raw bricks to the breeze created from the temperature difference in the air. This second method did not call for a direct expose of the brick to the sun. These methods were performed during different stages of brickmaking. The first method was performed anywhere from the beginning to the middle stage of the drying phase while molding the mixture and flipping the raw bricks, and the second was performed at the end of the drying phase when the brick was dried in the open air (see Figure 1).

The first stage of the drying phase was done simultaneously with the process of brick molding. The bricks were molded and then arranged with spaces around them to be heated by the sun. The process of molding the bricks on the flat ground demonstrated the efficiency of the craftsmanship. The brick was created by pressing the mud inside a mold and then releasing the brick mixture from the molding device. The molding device consisted of rectangle frames of varying sizes, thickness and additional extensions made from wood, glass, or acrylic. The extensions and thickness of brick size served as references for the craftsmen during the mixing process. Due to the process of pressing and the shorter dimension, the resulting molded, raw bricks appeared flat (Figure 1-A). The pressed brick was no longer movable and was then left to dry while the craftsmen continued molding the next brick.

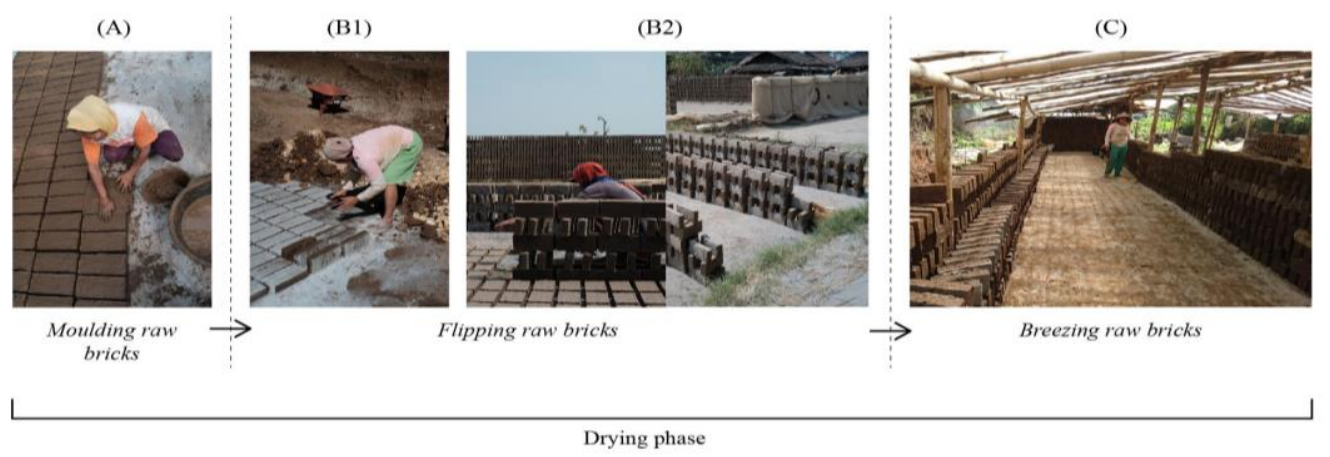

Figure 1 Stages of the drying phase of traditional brickmaking 
At this stage, the heat from the sun was expected to be at its maximum during the day, which meant, the more surfaces of the bricks that were facing the sun, the better. The molding devices increased the amount of surface exposure as the molded, raw bricks were laid down so that they had more surfaces facing the sun directly. Consequently, the surfaces directly absorbed large amounts of the sun's heat without the shape of the brick changing drastically. The shape of the devices also helped the craftsmen to mold the bricks faster as it provided a reference point for the craftsmen to lay out the next molded, raw brick. This also helped the craftsmen to work on the flat ground where the molded, raw bricks were laid out. Consequently, the devices facilitated the task and reduced the time required for molding the mixture into raw bricks on the available flat ground, hence allowing more time for the molded, raw bricks to be exposed to the sun.

After the molding process, the relatively dry, molded, raw bricks were then positioned with the side surface of the bricks touching the ground. This stage was the second part of the drying phase, during which the bricks were exposed directly to the sun. Some adjustments on the positions of the bricks on the flat ground were made as the spaces between the bricks did not need to be too large. As a result, the bricks were now more concentrated in one area of the flat ground (see Figure 1-B1), which was also helpful in preparing for the next stage of the drying phase. The craftsmen in Ambarawa and Welahan, had different approaches to flipping the bricks. While in Ambarawa the bricks were flipped 90 degrees in one horizontal plane (one layer), in Welahan, the craftsmen flipped the bricks and stacked them to form a wall (see Figure 1-B2), while still maintaining the gap between each brick.

The next stage in the drying phase demonstrated the second method of directly using the sun's heat. In this stage, the heat created a temperature difference which in turn, created a breeze of air. This breeze was needed to further dry the bricks. Therefore, compared to the previous stages in which enormous amounts of heat from direct sun exposure were expected, this stage only required breeze and not necessarily a direct exposure to the sun. The craftsmen attained such exposure by stacking the bricks at the side border of the field (see Figure 1-C). The stacks which formed both the wall bordering the field (Figure 1-C) and the shorter walls in the middle of the field (Figure 1-B2), were arranged in specific ways to ensure gaps in between the bricks to permit the flow of wind (see Figure 2). The craftsmen used repeated layers to arrange the bricks. The first arrangement appeared as the bottommost layer starts from the ground. It was then followed by the second layer with the second type of arrangement. The third layer used the arrangement in the first layer and the fourth layer used the arrangement from the second layer. This repetition continued until the brick wall attained the desired height. Furthermore, as seen in Figure 2, the craftsmen maintained the gap in each layer of the stacked bricks so that bricks on the lower layer could support the bricks on the higher layer. The arrangements of bricks and available wind and sun exposure determined when the drying phase ended and when the process continued to the firing phase. Due to the fluctuation of wind and sun exposure, the transition from the drying phase to the firing phase might change depending on environmental conditions.

Each stage in the drying phase demonstrated the various ways by which craftsmen utilized the heat from the sun to make sure that the raw bricks achieved the desired dryness while working on another phase or moving to the next phase. Interestingly, the craftsmen made sure not only that the heat of the sun reached the surfaces of the raw bricks, but also that environmental conditions (such as rain) did not interrupt the phase. As seen in Figure 1 (B2 and C), the craftsmen used a transparent water-resistant sheet (craftsmen in both brickmaking locations use plastic sheets) to block the rainwater. As the sheets were transparent, the heat from the sun still passed through and the drying process still 
continued even in nonoptimal weather conditions. The utilization of transparent sheets is a strategy used by craftsmen to simultaneously maximize the heat from the sun and keep out unwanted elements such as rain during the drying phases.
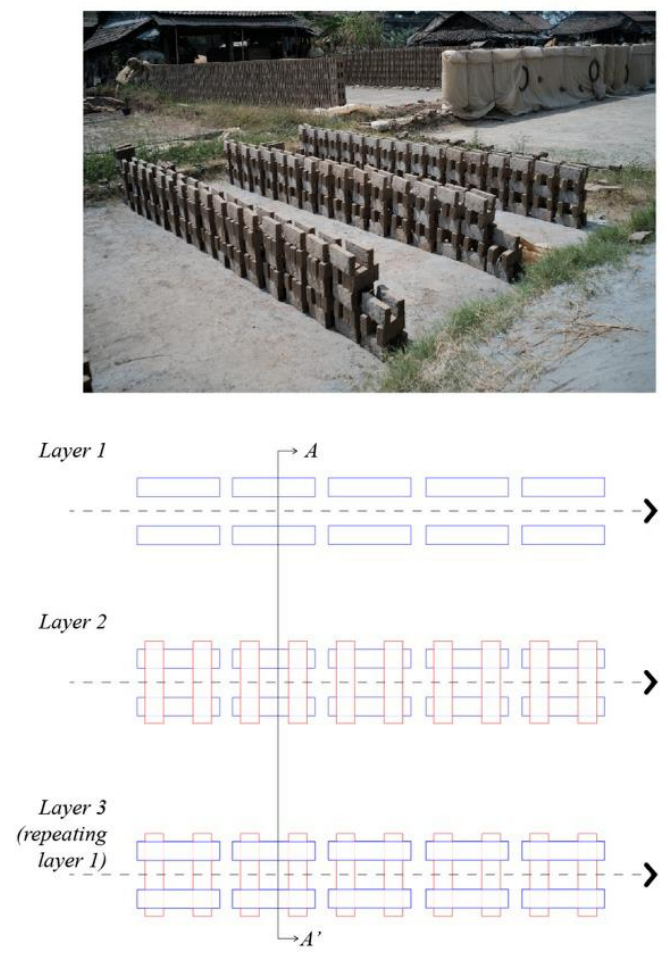

Layer 4 (repeating layer 2

Layer 5 (repetaing layer 1 ) and so on until the desired height

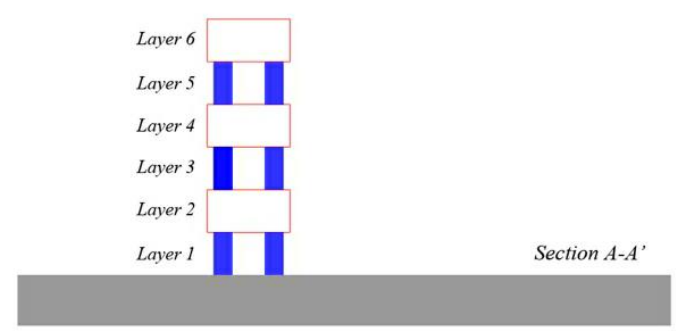

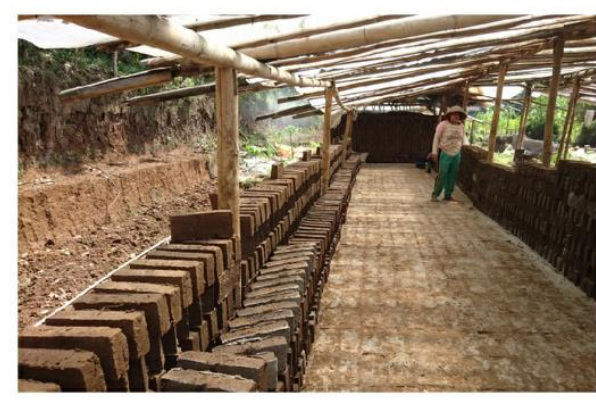

Layer 1

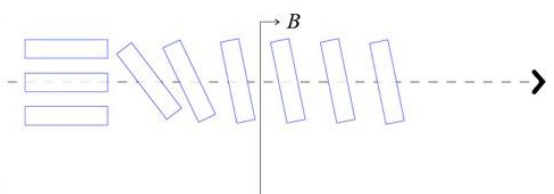

Layer 2
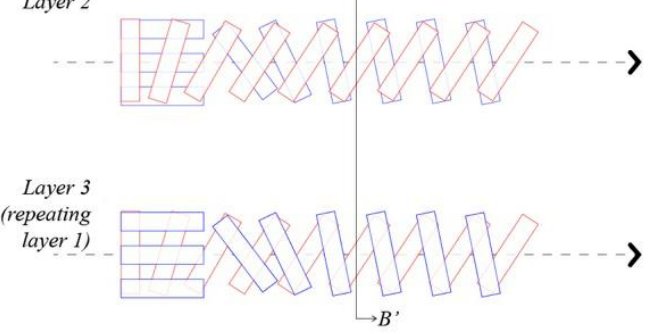

Layer 4 (repeating layer 2

Layer 5 (repetaing layer 1 ) and so on until the desired height

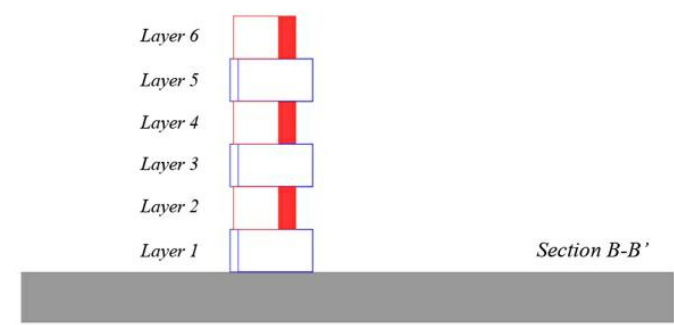

Figure 2 During the arrangement of raw bricks, the gap between each brick is maintained in certain ways

\section{Lessons from the Drying Phase of Traditional Brickmaking}

The sun-drying phase in traditional brickmaking, as observed at the two locations of the study, Ambarawa and Welahan, demonstrated the use of current energy as part of the ecological aspect of architecture material production. Such a use of current energy drove the stages and responses that shaped the process of sun-drying, from maximum exposure to less exposure to the heat from the sun in order to achieve a certain level of dryness. In achieving this dryness, what mattered was not only the environmental conditions but also the craftsmen's strategies of alternating between or maximizing different forms of current energy. These strategies influenced the way the bricks were laid down, arranged, positioned, stacked, and covered and were constrained by the consistency of the clay mixture, the field space availability, and the low-tech equipment that limited the potential interventions that could be performed during the process. Interestingly, the craftsmen's 
strategies and responses informed a production of architecture material intertwined with everyday life. They depicted spatial operations that were conducted in a quotidian environment instead of in a controlled and strict one (Atmodiwirjo and Yatmo, 2019). Other than the display of such strategies, the use of current energy also drove the fluctuating flow of the different production stages, influencing the beginning and the end of each phase beyond the drying phase.

This paper points out that the use of current energy, the craftsmen's strategies, and the fluctuating flow of brick production, which often consists of phases done simultaneously, provides potential knowledge for the future industrialization of brickmaking. An important lesson, for example, can be derived from the way efficiency is achieved through developing local strategies instead of relying on the innovation of the machines. In addition, while the fluctuating flow of brick production may not seem beneficial, it provides enough time to prepare for the firing process, which requires a high amount of an immediate form of energy and accumulation of material. In this sense, investigating the current energy use expands the understanding of efficient, ecological methods that focus on the interconnection between humans, materials, and the environment. This study, however, only focused on the qualitative aspects of the sun-drying phase. Future studies which focus more on the quantitative aspects of the process may develop a better understanding of such efficiency by exploring in detail, the temporality of the production process, measuring the time taken by craftsmen to mold, stack, arrange, and relocate each brick in order to inform the flow of overall brick production. In future studies, an airflow simulation might also be conducted to investigate the optimal gap needed between the bricks to dry them thoroughly.

\section{Acknowledgements}

This research is supported by Penelitian Dasar Ristekdikti 2020, a research grant (contract number: NKB-69/UN2.RST/HKP.05.00/2020) provided by The Ministry of Research, Technology and Higher Education of the Republic of Indonesia.

\section{References}

Atmodiwirjo, P., Johanes, M., Saginatari, D.P., Yatmo, Y.A., 2018. Ecological Aspects of the Traditional Brick Making Process in Pedurungan Kidul, Central Java. E3S Web of Conferences, Volume 67, p. 04034

Atmodiwirjo, P., Yatmo, Y.A., 2019. Interiority in Everyday Space: A Dialogue between Materiality and Occupation. Interiority, Volume 2(1), pp. 1-4

Atmodiwirjo, P., Yatmo, Y.A., 2020. Tanahku Indonesia: On Materialscape as the Materiality of a Nation. Architecture and Culture, pp. 1-22, DOI: 10.1080/20507828.2020.1774850

Baper, S., Khayat, M., Hasan, L., 2020. Towards Regenerative Architecture: Material Effectiveness. International Journal of Technology. Volume 11(4), pp. 722-731

Berawi, M.A., 2016. Accelerating Sustainable Infrastructure Development: Assuring WellBeing and Ensuring Environmental Sustainability. International Journal of Technology, Volume 7(4), pp. 527-529

Carey, J., 2018. Indeterminate duration. Interiority, Volume 1(2), pp. 185-202

Dalkılıç, N., Nabikoğlu, A., 2017. Traditional Manufacturing of Clay Brick used in the Historical Buildings of Diyarbakir (Turkey). Frontiers of Architectural Research, Volume 6(3), pp. 346-359

Darain, K.M.ud., Jumaat, M.Z., Islam, A.B.M.S., Obaydullah, M., Iqbal, A., Adham, Md.I., Rahman, Md.M., 2015. Energy Efficient Brick Kilns for Sustainable Environment. Desalination and Water Treatment, Volume 57(1), pp. 105-114 
Demir, I., 2008. Effect of Organic Residues Addition on the Technological Properties of Clay Bricks. Waste Management, Volume 28(3), pp. 622-627

Gomes, E., Hossain, I., 2003. Transition from Traditional Brick Manufacturing to More Sustainable Practices. Energy and Sustainable Development, Volume 7(2), pp. 66-76

Gualtieri, A.F., Ricchi, A., Gualtieri, L.M., Maretti, S., Tamburini, M., 2016. Kinetic Study of the Drying Process of Clay Bricks. Journal of Thermal Analysis and Calorimetry, Volume 123(1), pp. 153-167

Handayani, S., 2010. Kualitas Batu Bata Merah dengan Penambahan Serbuk Gergaji (Quality of Red Bricks with the Addition of Sawdust). Jurnal Teknik Sipil dan Perencanaan, Volume 12(1), pp. 41-50

Holley, I.B., 2009. The Mechanization of Brickmaking. Technology and Culture, Volume $50(1)$, pp. 82-102

Johanes, M., Wahid, A.R., 2018. Tanahku Indonesia: Celebrating the Indigenous Interior. Interiority, Volume 1(1), pp. 79-86

Kadir, A.A., Sarani, N.A., 2012. An Overview of Wastes Recycling in Fired Clay Bricks. International Journal of Integrated Engineering, Volume 4(2), pp. 53-69

Lakho, N.A., Zardari, M.A., 2016. Structural Properties of Baked Clay Bricks Fired with Alternate Fuels. Engineering, Volume 8(10), pp. 676-683

McDonough, W., 1996. Design, Ecology, Ethics and the Making of Things. In: Theorizing a New Agenda for Architecture: An Anthology of Architectural Theory. Princeton Architectural Press, pp. 400-407

Nuroso, H., Supriyadi., Sudarmin, S., Sarwi., 2018. Identification of Indigenous Science in the Brick-Making Process through Ethnoscience Study. Journal of Physics: Conference Series, Volume 983(1), pp. 1-5

Sadar, J.S., 2018. Quasi-Materials and the Making of Interior Atmospheres. Interiority, Volume 1(1), pp. 49-63

Sarkar, R., Kurar, R., Gupta, A.K., Mudgal, A., Gupta, V., 2017. Use of Paper Mill Waste for Brick Making. Cogent Engineering, Volume 4(1), pp. 1-15

Singh, A.L., Asgher, S., 2005. Impact of Brick Kilns on Land Use/Landcover Changes around Aligarh City, India. Habitat International, Volume 29(3), pp. 591-602

Sudarsana, I.K., Budiwati, I.A.M., Wijaya, Y.A., 2011. Karakteristik Batu Bata Tanpa Pembakaran Terbuat dari Abu Sekam Padi dan Serbuk Batu Tabas (Characteristics of Uncooked Bricks Made from Rice Husk Ash and Tabas Stone Powder). Jurnal Ilmiah Teknik Sipil, Volume 15(1), pp. 93-101

Tahir, S.N.A., Rafique, M., 2009. Emission of Greenhouse Gases (GHGs) from Burning of Biomass in Brick Kilns. Environmental Forensics, Volume 10(4), pp. 265-267

Wahid, A.R., Yatmo, Y.A., Paramita, K.D., 2020. More than Just a Material Perfection: Preserved Human-Environment Relationship in Traditional Brick-Making Scenarios. Journal of Physics: Conference Series, Volume 1655, pp. 1-7

Yusuf, M.F., Ashari, H., Razalli, M.R., 2018. Environmental Technological Innovation and Its Contribution to Sustainable Development. International Journal of Technology, Volume $9(8)$, pp. 1569-1578 